\title{
Critical Review on Informed Consent
}

\author{
Mirah Avisha ${ }^{1 *} \quad$ Slamet Sampurno ${ }^{2} \quad$ Indar $^{3} \quad$ Arsunan Arsin ${ }^{3}$ \\ 1.Master Program of Law, Postgraduate of Hasanuddin University \\ 2.Faculty of Law, Hasanuddin University \\ 3.Faculty of Public Health, Hasanuddin University \\ **29, J1 Harimau Makassar, Indonesia 90124
}

\begin{abstract}
This study aims to determine the implementation of informed consent at the Sitti Khadijah I Muhammadiyah Mother and Child Hospital Makassar. This study was conducted using normative research methods. The results of this study concluded that informed consent had been carried out and used the form in accordance with the juridical review, but the filling had not appropriately done, and at the time of implementation there were still a few deficiencies.
\end{abstract}

Keywords: Medical Law; Therapeutic Agreement; Informed Consent.

DOI: $10.7176 / \mathrm{JLPG} / 89-24$

Publication date:September $30^{\text {th }} 2019$

\section{1) INTRODUCTION}

Every person has the right to obtain health services as stipulated in the Constitution of $1945 \mathrm{Article} 28 \mathrm{H}$, because health is a human right and is an element of welfare that must be realized in accordance with the ideals of the Indonesian nation. ${ }^{1}$

Efforts to improve the highest level of health at first are in the form of an effort to cure the disease and then gradually develop towards the integration of health services for the whole community by involving a wider community which includes promotive, preventive, curative, and rehabilitative efforts that are thoroughly integrated and sustainable. ${ }^{2}$

Every person has the right to obtain information about his health data including the actions and treatments that he has received or will receive from health workers, and has the right to accept or reject some or all of the aid services that will be given to him after receiving and understanding information about these actions in detail ${ }^{3}$ This is in line with article 8 and article 56 number (1) of Law Number 36 of 2009 concerning Health.

This is supported by Article 45 of Law Number 29 of 2004 concerning Medical Practices which states: "Every medical or dentistry action which will be carried out by a doctor or dentist on a patient must obtain approval, which is given after the patient has received a complete explanation that at least includes the diagnosis and procedure for medical action, the purpose of the medical action, other alternatives and the risk, complications that might occur, and the prognosis for the action. Such approval can be given both in writing and orally, but every action that carries a high risk must be given with written approval and signed by the person who has the right to give consent."

The agreement is called Informed Consent which in article 1 of Regulation of Minister of Health Number 290/MENKES/PER/III/2008 which states the consent given by the patient or family after obtaining a full explanation of the medical or dental action that will be carried out to the patient.

Because of the agreement, a relationship or agreement called a therapeutic agreement is formed. However, the agreement does not guarantee to heal or benefit the patient because the object of this agreement is not the result but the effort made to cure the patient. ${ }^{4}$ Yet, some problems and obstacles arise in daily practice such as the language in delivering the information, the limit of the amount of information that must/can be given, the unequal form of informed consent, errors in filling out the informed consent form and problems in the interference of family or third parties in terms of giving consent ${ }^{5}$, which cause miscommunica - tion by the patient so that if something happens that harms the patient, the patient will assume the doctor has taken a malpractice action, without first seeing the treatment process whether it is in accordance with the procedure or not. $^{6}$

Sitti Khadijah I Muhammadiyah Mother and Child Hospital is a type C specialty hospital, with facilities and capabilities of medical services for obstetrics and gynecology specialists, several subspecialists and pediatric medical services. The obstetrical and gynecological services include emergency services, delivery rooms,

\footnotetext{
${ }^{1}$ Constitution of the Republic of Indonesia of 1945, Article $28 \mathrm{H}$

${ }^{2}$ Law of the Republic of Indonesia Number 36 of 2009 concerning Health

${ }^{3}$ Amir Ilyas, (2014), Pertanggung Jawaban Pidana Dokter dalam Maplraktek Medik di Rumah Sakit, Yogyakarta: Rangkang Education. hlm.

${ }^{4}$ Desriza Ratman, Aspek Hukum Informed Consent dan Rekam Medis Dalam Transaksi Terapeutik, Bandung: Keni Media, 2013, p. 15-16

${ }^{5}$ Indar (b), Etikolegal Dalam Pelayanan Kesehatan, Yogyakarta: Pustaka Pelajar, 2017, hlm.309 - 310

${ }^{6}$ Muji Iswanty, dkk, (2018), Hukum Kesehatan Dimensi Etis dan Yuridis Tanggung Jawab Pelayanan Kesehatan, Yogyakarta: Litera, hlm. 88
} 
inpatient and outpatient services, which often involve medical treatment to patients covering a variety of cases, which requires prior informed consent. The available forms and their implementation are the main reasons for the authors to examine the thesis entitled "Legal Analysis of Regulation of Minister of Health Number 290/MENKES/PER/III/2008 concerning Informed Consent at RSIA Sitti Khadijah I Muhammadiyah Makassar”. This study aims to determine the implementation of informed consent at RSIA Sitti Khadijah I Muhammadiyah Makassar.

\section{2) RESEARCH METHODS}

\subsection{Types and Nature of Research}

The type of this research was normative legal research which was a legal research that studies written law from various aspects of theory, history, philosophy, comparison, structure, composition, scope, and material of general explanation consistency, and article by article. The type of research used to answer the problem and elaborate on the subjects that had been prepared in this study was a descriptive type, with an applied normative approach (applied law research) that was a legal research applying normative legal provisions directly to any particular legal event that occurs in society. ${ }^{1}$

\subsection{Population and Sample}

a. Population

All doctors who work at RSIA Sitti Khadijah I Muhammadiyah Makassar and patients who receive both elective and emergency cesarean section.

b. Sample

Doctors who are in charge of Emergency Services, Delivery Room Services, and Inpatient Services and patients treated in Emergency Services, Delivery Room Services, and Inpatient Services.

\subsection{Data Collection}

Data collection techniques are techniques for collecting data from one or several data sources that are determined. In a study, there are at least three types of data collection techniques, including: the study of documents or library materials, examinations or observations, and interviews (Soerjono Soekanto, 2006: 21). To obtain complete and relevant data, the data collection techniques used by the author were as follows:

a. Field Study

Data collection techniques in the field study were carried out through interviews. Interview is a way to obtain data by doing question and answer directly with the primary data source.

b. Literature Review

Literature study is a data collection technique using several literary books, legislations, documents and other written sources to obtain material related to the problem under study.

\subsection{Processing and Data Analysis}

The step taken after obtaining the data is to analyze the data. Data analysis has an important position in research to achieve research objectives. In terms of analyzing data, the authors used an interactive analysis model in the form of a cycle consisting of three main components, including:

a. Data Reduction

It was a process of selecting, focusing and simplifying the data. This process continued until the end of the research report.

b. Data Display

Presentation of data in the form of a description of a narrative that allowed conclusions to be made. Presentation of the data must refer to the formulation of the problem, so that the answers could be obtained from the problem under study.

c. Conclusion Drawing

Final conclusions would not occur until the data collection process ended, so it needed to be verified in order to be accountable.

\section{3) RESULTS and DISCUSSION}

Implementation of Regulation of Minister of Health Number 290/MENKES/PER/III/2008 concerning Informed Consent at RSIA Sitti Khadijah I Muhammadiyah Makassar

Sitti Khadijah I Muhammadiyah Mother and Child Hospital Makassar is a private hospital located on R. A. Kartini Street Number 15-17 Makassar South Sulawesi. RSIA Sitti Khadijah I Muhammadiyah Makassar is also a teaching hospital in which the implementation of health care and services must be in accordance with the

\footnotetext{
${ }^{1}$ Junaedi Efendi dan Johnny Ibrahim, Metode Penelitian Hukum Normatif dan Empiris, Depok: Prenamedia Group, 2018 p. 123
} 
procedures and stages of education.

Based on the results of the authors' research through data collection from the medical records of RSIA Sitti Khadijah I Muhammadiyah Makassar, the number of patients undergoing surgery in the last 3 years can be seen in the table below:

Table 1. Number of Surgery

\begin{tabular}{lll}
\hline \multirow{2}{*}{ Year } & \multicolumn{2}{l}{ Number of Surgery } \\
\cline { 2 - 3 } & Caesarean Section & Non-Caesarean Section \\
\hline $\mathbf{2 0 1 6}$ & 2554 & 650 \\
$\mathbf{2 0 1 7}$ & 2441 & 600 \\
$\mathbf{2 0 1 8}$ & 2432 & 751 \\
\hline
\end{tabular}

Source: Data of RSIA Sitti Khadijah 1 Muhammadiyah Makassar

Based on the authors' analysis from the table above, it can be seen that the number of high-risk medical treatments in Sitti Khadijah I Muhammadiyah Makassar over the past 3 years was quite high although there was a slight decrease each year. Thus, the implementation of informed consent needed to be considered whether it was appropriate or not.1

1) Legislation Provisions as the Basic of Informed Consent;

a. Article 8 and article 56 number (1) of Law Number 36 of 2009 concerning Health.

b. Regulation of Minister of Health Number 290/MENKES/PER/III/2008 concerning Informed Consent

c. Article 45 of Law Number 29 of 2004 concerning Medical Practices

d. Regulation of Minister of Health Number 1419/Menkes/Per/X/2005 concerning the Implementation of Practices of Doctors and Dentists

e. Civil Code of Article 1321 that "There is no valid agreement if the agreement was obtained by force or fraud"

2) Informed Consent Form at RSIA Sitti Khadijah I Muhammadiyah Makassar

The informed consent form that was provided at RSIA Sitti Khadijah I Muhammadiyah Makassar took the form of a standard agreement whose form and contents had been determined by the Indonesian Medical Council (KKI), but there were slight differences in the witness section. The informed consent form used at RSIA Sitti Khadijah I Muhammadiyah Makassar was not uniform in the witness section, there were several forms that were still signed by 1 witness (only from the hospital) and there were also 2 witnesses (the hospital and the patient) which should be based on KKI. This was done to facilitate the filling and maintain compliance with the standards of an informed consent, so that it could be a strong evidence when a dispute arised.

The informed consent form available at RSIA Sitti Khadijah I Muhammadiyah Makassar contained:

a. Header containing the hospital logo and name, form sheet code, patient identity (medical record number, name, date of birth, gender, age, and ward), statement of approval or rejection of medical action.

b. Provision of information containing the name of the doctor implementing the action, the information provider, and the recipient of the information/approver.

c. The type of information containing the diagnosis, the basis of the diagnosis, medical actions, indications of action, procedures, goals, risks, complications, prognosis, alternatives and risks, etc.

d. Signatures showing that have given and received the information

e. The identity signing the agreement or rejection containing the name, age, gender and address

f. Description of time and place

g. The name and signature of the patient who made the consent

h. The witness's name and signature

3) Implementation of Informed Consent at RSIA Sitti Khadijah I Muhammadiyah Makassar

Before the doctor performing medical treatment, the doctor is obliged to provide information about the type of illness suffered by the patient and the medical action to be taken to save the life of the patient and the risks that may arise from the medical action to the patient and his family. ${ }^{2}$ Permanent procedures for taking medical actions that are permanent and binding are the patient's consent to take medical treatment. Acceptance from these patients is filled in the form of informed consent. This informed consent form has generally been prepared in such a way that the doctor/hospital and the patient only needs to fill in the column provided for this after explaining verbally to the patient or the patient's family. ${ }^{3}$

Because informed consent is an agreement to take medical action, the existence of an informed consent is

\footnotetext{
${ }^{1}$ Triana Ohoiwatun, Bunga Rampai Hukum Kedokteran, Malang: Bayumedia Publishing, 2007

${ }^{2}$ Khare, Anshika \& Saxena, Vrinda \& Jain, Manish \& Sharva, Vijayta \& Singh, Prakash \& Dayma, Ashwini. (2017). Knowledge and attitude toward informed consent in medical and dental practitioners, of Bhopal City, India. Journal of Dental Research and Review

${ }^{3}$ Jukic, Marko \& Kvolik, Slavica \& Kardum, Goran \& Kozina, Slavica \& Juraga, Ana. (2009). Knowledge and Practices of Obtaining Informed Consent for Medical Procedures among Specialist Physicians: Questionnaire Study in 6 Croatian Hospitals. Croatian medical journal.
} 
very important for those who make a health service agreement, so it can be seen that the existence of an informed consent is very important and necessary in the hospital. The problem is whether the contents of the informed consent form have met the legal requirements for the agreement ${ }^{1}$

According to Guwandi, Informed Consent states at least 4 components contained, including:

a. Patients must have the capacity or ability to make decisions;

b. Doctor must provide information about the actions to be taken, testing, or procedures, including benefits and risks that may occur;

c. Patients must understand the information provided;

d. Patients must voluntarily give their permission without coercion or pressure.

To every patient who would undergo medical treatment at RSIA Sitti Khadijah I Muhammadiyah Makassar, informed consent was given by the doctor. After an agreement was made, an informed consent form would be offered, both the approval and rejection forms in the form of a standard form in the following format:

1) Header of approval or rejection statement of medical action;

When a medical action would be taken, the patient/family who was entitled to give consent was carried out Informed Consent. The informed consent form in RSIA Sitti Khadijah I Muhammadiyah Makassar was in the form of a standard agreement form that had been determined by the Indonesian Medical Council (KKI) consisting of 2 forms, including:

a. Approval form of informed consent; and

b. Rejection form of informed consent.

These forms were used after the patient who had the right to sign consent was given a detailed explanation of the diagnosis of the disease, the actions to be taken, the risks that may occur and the prognosis after the medical treatment. The hospital and medical personnel who will perform medical treatment will respect any decision from the patient or family to determine whether to agree or refuse to take medical action. After an agreement is made, the patient/family will be offered a form according to the agreement that is the rejection form or approval form of the medical action. The identity of the patient who signed the medical action agreement consisting of name, age/gender, and address. The identity of the party that signed the medical action agreement must be complete, bearing in mind that if a dispute occurs later in the day it is clear who is responsible for the approval or rejection of the medical action. The identity that has been filled in by the patient on the Informed Consent form at RSIA Sitti Khadijah I Muhammadiyah Makassar is considered quite complete.

2) A statement explaining that the patient has understood and comprehended the explanation given by the doctor; consisting of: ${ }^{2}$
a. Diagnosis;
b. Rationale of the Diagnosis
c. Medical Treatment
d. Action Indications
e. Procedures
f. Purpose
g. Risk
h. Complications
i. Prognosis
j. $\quad$ Alternatives and Risks

Based on the Law Number 29 of 2004 concerning Medical Practices Article 45 Section (3), it states that Informed Consent must at least cover:

a. Medical diagnosis and procedure;

b. Purpose of the medical treatment taken;

c. Other alternative actions and risks;

d. Possible risks and complications; and

e. Prognosis for actions taken.

Based on the provisions of the Law, the Informed Consent form at RSIA Sitti Khadijah I Muhammadiyah Makassar has fulfilled the requirements.

3) Status of signatories to approval for medical treatment; including from the patient himself, wife, husband, child, father/mother

The parties of the patients who are entitled to sign the approval or rejection of medical actions can be given by the patient or family as regulated in the Explanation of Law Number 29 of 2004 concerning Medical Practices article 45 section (1). Patients who are entitled to sign the medical agreement consist of: the patient himself, wife,

\footnotetext{
${ }^{1}$ Nnabugwu, Ikenna \& Ugwumba, Fred \& Udeh, Emeka \& Anyimba, Solomon \& Ozoemena, Oyiogu. (2017). Informed consent for clinical treatment in low-income setting: Evaluating the relationship between satisfying consent and extent of recall of consent information. BMC Medical Ethics.

${ }^{2}$ Indar (a), Konsep dan Perspektif Etika dan Hukum Kesehatan Masyarakat, Yogyakarta: Pustaka Pelajar, 2018
} 
husband, biological children, biological father/mother, or siblings.

In fact, as the format of the signatory status in the Informed Consent form provided at the RSIA Sitti Khadijah I Muhammadiyah Makassar only provided a choice: on me/(empty column) me. Therefore, to adjust to the explanation of the Law, information should be added that in addition to the patient who is entitled to give a statement only the wife, husband, biological children, biological father/mother, or siblings.

4) The identity of the patient to be taken for medical treatment, consisting of name, age/sex, address, place of care ie room or ward, class and medical record number.

The filling of the complete patient identity including the place of care, the medical record number is an absolute requirement for approval of medical treatment. This is to avoid mistakes that might occur if the patient's identity is not written in detail. Some cases of medical action errors occur due to the lack of detail of the identity of the patient concerned, so that medical action is carried out on different patients. This can be fatal.

The format for filling in the patient's identity in the informed consent form that has been provided at RSIA Sitti Khadijah I Muhammadiyah Makassar is quite complete and detailed and it is expected that there will be no wrong target for medical treatment.

5) A statement stating that the signatory of the informed consent is made with full awareness and not under duress.

It is an absolute requirement that the decision to reject or approve medical treatment is done voluntarily and not under duress.

This is based on Article 1321 of the Civil Code that: "There is no valid agreement if the agreement was obtained by force or fraud".

The hospital or doctor functions as a health servant according to their duties and obligations. The doctor will try all actions based on scientific and ethical medical practices. The doctor will try to explain in detail the medical action plan that will be done and the magnitude of the benefits for the patient, but the decision maker whether a medical action will be done or not to the patient is the full right of the patient or the family. Thus, all these decisions are an agreement between the doctor and the patient made in a voluntary and without coercion. If the rule is violated, then the Informed Consent has been done is not valid.

The Informed Consent Form available at RSIA Sitti Khadijah I Muhammadiyah Makassar has fulfilled the requirements under Article 1321 of the Civil Code.

6) The name and signature of the doctor who provided the informed consent explanation.

The name and signature of the doctor who provided the Informed Consent explanation is very important because if there is a dispute against the patient, it will easily provide confirmation of the case. It is better if the doctor's full name is written clearly and completely in the Informed Consent form, so there is no difficulty if confirmation is needed.

7) The name and signature of the patient who approved the medical action.

The name and signature of the patient who approved the medical action is very important because if a dispute occurs later, it will easily provide confirmation of the case. The full name should be clearly stated on the Informed Consent form. The party giving the signature on the Informed Consent form is the party who, based on the explanation of Law Number 29 of 2004 Article 45 section (3), has the right to give approval for medical treatment.

8) The name and signature of the witnesses consisting of 2 (two) people.

Witnesses who are entitled to sign the agreement on medical treatment based on the Regulation of Ministry of Health Number 585 of 1989 Article 4 section (3) are witnesses from the family and witnesses of a nurse or other paramedics. RSIA Sitti Khadijah I Muhammadiyah Makassar has not explained who the witnesses are. To avoid things that are not desirable in the event of a dispute in the future, it should be clearly stated who is entitled to be a witness. Witnesses, including nurses or other paramedics from the hospital, are needed to strengthen testimony in court in case of disputes. However, matters regarding witnesses are not listed in the Regulation of Ministry of Health Number 290/Men.Kes./Per/III/2008 concerning Approval of Medical Measures which is the latest Regulation of Ministry of Health for approval of medical action.

From the data above, in general the informed consent form contained at RSIA Sitti Khadijah I Muhammadiyah Makassar has fulfilled the main elements that must be contained in an informed consent as regulated in Law Number 29 of 2004 concerning Medical Practice, Minister of Health Regulation 290/Men.Kes./Per/III/2008 concerning Informed Consent, Article 1320 and Article 1321 of the Civil Code.

However, based on the Explanation of Law Number 29 of 2004 regarding Medical Practices Article 45 section (1) number 3, and the Regulation of Ministry of Health Number 290/Men.Kes./Per/III/2008 concerning Informed Consent, there are several things which according to the authors need to be added to the form, including:

1) Those who have the right to represent the patient in signing the informed consent are husband, wife, biological father/mother, biological children and siblings. In fact, the choice of the status of the signatory on the informed consent form provided in the form is only on me/(blank column) me, so that anyone can give consent. For this reason, it is necessary to have an additional choice of signing status in the form, including 
husband, wife, biological father/mother, biological children and siblings to comply with the provisions in the Explanation of Law Number 29 of 2004 concerning Medical Practice Article 45 section (1) number 3.

2) In the form provided, it is necessary to mention who is entitled to become a witness. Witnesses, including nurses or other paramedics from the hospital, are needed to strengthen testimony in court in case of a dispute with the patient. It is also needed to make uniformity of the forms because there are some that only require the signature of 1 witness and there are also 2 witnesses.

RSIA Sitti Khadijah I Muhammadiyah Makassar is a teaching hospital for obstetrics and gynecology. These fields are supported by personnel in the field of health, among others, there are obstetricians with the status of clinic educator doctors who assist general practitioners who are undergoing specialist education (residents), nonspecialist doctors, clinical educators, general practitioners, nurses, midwives, and other personnel health.

The ones who implement medical procedures in this field are specialist doctors and residents. This is based on the Indonesian Medical Council Decree which issues a Doctor Registration Certificate (STR) and is strengthened by the decision of the Obstetrics and Gynecology Specialist Association that every general practitioner who is studying in Obstetrics and Gynecology has competence in the field of The Science of Obstetrics and Gynecology including carrying out all the specialist actions under the guidance/approval of the doctor of Obstetrics and Gynecology Consultants.

In order to assess the implementation of informed consent at RSIA Sitti Khadijah I Muhammadiyah Makassar, the authors have conducted research from 2 May 2019 to 2 June 2019. The research was conducted by taking 50 samples of cases of the implementation of informed consent in that range of time. The author reviews the implementation of informed consent by:

a. Looking for patients who will be taken medical treatment;

b. Check and analyze the informed consent form that has just been implemented.

c. Interviewing doctors who provide explanations of the informed consent

d. Analyzing the implementation of the informed consent both forms that have been filled and the doctor's understanding of the informed consent that has been done

In a predetermined range of time, the authors examined the implementation of the informed consent that that has been done by:

a. Examining the informed consent form that has been filled, then analyzing based on the applicable law whether all parts that should have been filled out and carried out by the doctor and the patient were completely filled out.

b. The researchers conducted interviews with physicians who filled the informed consent with guidance on the sequence of questions that have been made by the researchers.

c. Analysis of the filling of Informed Consent at RSIA Sitti Khadijah I Muhammadiyah Makassar

Based on the research on filling out the informed consent form that has been carried out, the results obtained are: 1) Patient identity

The patient identity written down on the form consisted of the medical record number, the patient's name, gender, date of birth, age, and patient care room. From the examination of 50 informed consent forms that had been obtained, $50(100 \%)$ forms had been completely filled out. Thus, in the event of a dispute with the patient in the future, the doctor and hospital can prove that the patient who has taken the medical action is the right patient.

2) Provision of Information

In the column for providing information, there was the name of the doctor carrying out the action, the name of the information provider, and the name of the information recipient/the /approver. From the examination of 50 informed consent forms that had been carried out, it was obtained:

a. 10 forms $(20 \%)$ did not provide the full name of the doctor implementing the action

b. 41 forms $(82 \%)$ did not provide the full name of the person providing the information

c. 27 forms $(54 \%)$ did not fill in the clear name of the information recipient/the approver

d. 1 form (2\%) error in filling out the name of the information recipient/the approver

e. 2 forms (4\%) without an information provider's signature

f. 48 forms $(96 \%)$ contained the signature of a specialist doctor in the information provider column, whereas it is known that the person providing the information is a resident if the patient is a patient from a clinical teaching specialist doctor, and an UGD general practitioner, nurse, or midwife if the patient is a patient from a specialist doctor non clinical educator.

g. 50 forms $(100 \%)$ provided the signature of the patient receiving the information approver

Although this was a negligence (culpa), it would weaken the position of the doctor/hospital in the event of a dispute in the future, where the evidence in the form of the informed consent form became less strong due to the unclear identity of the signed informed consent from the patient.

3) Filling in the type of information provided

In the column for information provision, there is a diagnosis, rationale of the diagnosis, medical action indication of action, procedures, goals, risks, complications, prognosis, and alternatives \& risks. From the examination of 
50 informed consent forms that had been carried out, it was obtained:

a. 50 forms $(100 \%)$ were filled out with a complete and correct diagnosis

b. 50 forms $(100 \%)$ were filled out with the rationale of the diagnosis completely and correctly

c. 50 forms $(100 \%)$ were filled out with complete and correct medical actions

d. 1 form $(2 \%)$ was not filled with an indication of action

e. 50 forms $(100 \%)$ were filled out in a complete and correct manner

f. 50 forms $(100 \%)$ were filled out the objectives completely and correctly

g. 50 forms $(100 \%)$ were filled out with the risk completely and correctly

h. 50 forms $(100 \%)$ were filled out with complete and correct complications

i. 50 forms $(100 \%)$ were filled out with a complete and correct prognosis

j. 50 forms $(100 \%)$ were not filled out with alternatives and risks completely and correctly

Even though this was a negligence (culpa), it would weaken the position of the doctor/hospital if a dispute occured in the future, where the evidence in the form of an informed consent form became less strong because the form was not filled out completely.

4) Informed Consent Signatory's Identity

In the signatory's identity column, there was name, age, gender, address and relationship with the patient sections. From the examination of 50 informed consent forms that have been carried out, it was obtained:

a. 50 forms $(100 \%)$ were filled out the name, age, gender, and address clearly.

b. 50 forms $(100 \%)$ were filled out the age requirement for the signing of an informed consent age over 21 years or have been married based on the Regulation of Ministry of Health.

c. 43 forms $(86 \%)$ were signed by the patient's husband, each 1 form $(2 \%)$ was signed by the patient himself, biological mother, younger sibling, and patient's parents-in-law, and there were 3 forms $(6 \%)$ not filled with the patient's relationship status. Based on this, 1 form $(2 \%)$ was not in accordance with the provisions of Law Number 29 of 2004 concerning Medical Practice, Article 45 section (1) number 3. 5) Name and Signature of the Witness

There were 2 types of informed consent forms at RSIA Sitti Khadijah I Muhammadiyah Makassar, including 1 witness and 2 witnesses in which in this study there were 23 forms with 1 witness and 27 forms with 2 witnesses. For the 23 forms with 2 witnesses, all of them (100\%) contained the names and signatures of the hospital and for the 27 forms with 2 witnesses, there were 23 forms (46\%) filled with the full names and signatures of the witnesses from the patient and the hospital and 4 forms $(8 \%)$ filled with witnesses from the hospital only. This condition will be detrimental to the doctor and the hospital if there is a dispute with the patient due to the lack of evidence of informed consent that has been made due to the absence of relevant witnesses. The witness is a vital component before the Court because the witness's testimony will strengthen the truth or error in the implementation of informed consent.

\section{4) CONCLUSIONS}

In this study, it is known that the implementation of the informed consent at RSIA Sitti Khadijah 1 Muhammadiyah Makassar has been carried out with the form in accordance with the format determined by the Indonesian Medical Council (KKI), has fulfilled the main elements regulated in Law Number 29 of 2004 , Regulation of Ministry of Health Number 290/Men.Kes/Per/III/2008, and the legal aspects of the agreements article 1320 and 1321 of the Civil Code. However, on the filling there are still many elements that are incomplete.

\section{REFERENCES}

Ali, et al. (2006). Kemitraan Dalam Hubungan Dokter - Pasien. Jakarta: Konsil Kedokteran Indonesia.

Ilyas, A. (2014). Pertanggung Jawaban Pidana Dokter dalam Maplraktek Medik di Rumah Sakit, Yogyakarta: Rangkang Education.

Ratman, D. (2013). Aspek Hukum Informed Consent dan Rekam Medis dalam Transaksi Terapeutik. Bandung: Keni Media.

Jonaedi, E., \& Ibrahim. (2016). Metode Penelitian Hukum. Depok: Prenadamedia Group.

Guwandi, J. (2004). Hukum Medic (Medical Law). Jakarta: Balai Penerbit Fakultas Kedokteran Universitas Indonesia Jakarta.

Hanafiah., \& Amri, A. (200). Etik Kedokteran dan Hukum Kesehatan. Jakarta: EGC.

Indar. (2017). Etikolegal dalam Pelayanan Kesehatan. Yogyakarta: Pustaka Pelajar.

, (2018) Konsep dan Perspektif Etika dan Hukum Kesehatan Masyarakat. Yogyakarta: Pustaka Pelajar.

Jukic, M. et al. (2009). Knowledge and Practices of Obtaining Informed Consent for Medical Procedures among Specialist Physicians: Questionnaire Study in 6 Croatian Hospitals. Croatian medical journal.

Khare, A. et al. (2017). Knowledge and attitude toward informed consent in medical and dental practitioners, of Bhopal City, India. Journal of Dental Research and Review.

Koeswadji, H. H. (1998). Hukum Kedokteran (Studi tentang Hubungan Hukum Dalam Mana Dokter Sebagai 
Salah Satu Pihak). Bandung: Citra Aditya Bakti

Konsil Kedokteran Indonesia. (2006) Manual Persetujuan Tindakan Kedokteran, Jakarta.

Muji, I. et al. (2018). Hukum Kesehatan Dimensi Etis dan Yuridis Tanggung Jawab Pelayanan Kesehatan, Yogyakarta: Litera

Nnabugwu, I. et al. (2017). Informed consent for clinical treatment in low-income setting: Evaluating the relationship between satisfying consent and extent of recall of consent information. BMC Medical Ethics.

Notoatmodjo, S. (2010). Etika dan Hukum Kesehatan. Jakarta: Rineka Cipta.

Ohoiwutun, T. (2007). Bunga Rampai Hukum Kedokteran. Malang: Bayumedia.

Purwadianto, A. et al. (2012). Kode Etik Kedokteran Indonesia. Jakarta: Ikatan Dokter Indonesia.

Rafly, et al. (2006). Penyelenggaraan Praktik Kedokteran Yang Baik Di Indonesia. Jakarta: Konsil Kedokteran Indonesia.

Soeraryo, D. (2004). Etik, Hukum Kesehatan Kedokteran (Sudut Pandang Praktikus), Bagian Ilmu Kedokteran Forensik \& Medikolegal Fakultas Kedokteran Universitas Diponegoro, Semarang.

Veronica, K. (2002). Peranan Informed Consent Dalam Transaksi Terapeutik. Bandung: PT. Citra Aditya Bakti

\section{Legislations}

Directorate General of Medical Services (1999). Guidelines for Informed Consent. Jakarta: Department of Health of Republic of Indonesia.

Code of Civil Law

Criminal Code

Indonesian Medical Ethics Code

Constitution of 1945

Law Number 29 of 2004 concerning Medical Practices

Law Number 36 of 2009 concerning Health

Law Number 44 of 2009 concerning Hospitals

Law Number 36 of 2014 concerning Health Workers

Regulation of Ministry of Health Number 290/Men.Kes./Per/III/2008 concerning Approval of Informed Consent 